\title{
Phenotypic charactenization of Schistosoma mansoni adult worms recovered from undernourished mice: a morphometric study focusing on the reproductive system
}

\author{
Caracterização fenotípica de vermes adultos de Schistosoma mansoni \\ recuperados de camundongos desnutridos: estudo \\ morfométrico do sistema reprodutor
}

\author{
Renata Heisler Neves ${ }^{1}$, Sheila Andrade de Oliveira², José Roberto Machado-Silva1, \\ Eridan Coutinho ${ }^{2}$ and Delir Corrêa Gomes ${ }^{3}$
}

\begin{abstract}
A morphometric study focusing on some features of the reproductive system of Schistosoma mansoni adult worms was performed, aiming to complete previously reported data concerning the effects of undernourishment of the host on the parasites. Male worms were significantly affected $(p<0.05)$ regarding the testicular lobes.
\end{abstract}

Key-words: Schistosoma mansoni. Nutritional status. Morphometric study. Phenotypic plasticity.

Resumo Foi realizado um estudo morfométrico de alguns elementos do sistema reprodutor de machos e fêmeas de Schistosoma mansoni, objetivando complementar estudo anterior sobre os efeitos da desnutrição do hospedeiro sobre os parasitos. Alterações significativas ocorreram em parasitos machos $(p<0,05)$, em relação aos lobos testiculares.

Palavras-chaves: Schistosoma mansoni. Estado nutricional. Estudo morfométrico. Plasticidade fenotípica.

Schistosomiasis mansoni and malnutrition are pathologies that can simultaneously occur in developing areas such as Northeastern Brazil ${ }^{4}$. The difficulty in undertaking longitudinal studies in human populations has justified the development of experimental models ${ }^{8}$. Malnutrition has been considered as a factor able to modify the host-parasite-environment system, aggravating the course of schistosomiasis by breaking the equilibrium in the relationships among the components of this system ${ }^{3}$.

Brightfield, scanning electron microscopy and confocal laser scanning microscopy (CLSM) have been used in morphological studies of Schistosoma mansoni adult worms ${ }^{9111213141520}$. Besides the known effects on the course of the infection, malnutrition of the host leads to a reduction in the worm body length and in the distance between the suckers in males, as well as changes in the reproductive system of male and female worms ${ }^{21}$. These findings were also confirmed by confocal laser scanning microscopy (CLSM) ${ }^{19}$.

This paper aims to bring some additional information concerning the effects of the undernourishment of the host on male and female adult Schistosoma mansoni.

Swiss Webster mice were percutaneously infected with 80 cercariae (BH strain). Undernourished animals were fed a multideficient and essentially low protein diet (Regional Basic Diet-RBD) ${ }^{5}$. Well-fed control mice ingested a standard commercial diet (Nuvilab CR-1). Mice were sacrificed 75 days post-infection and worms were recovered by perfusion technique ${ }^{7}$. All specimens were fixed in $10 \%$ formalin, stained with carmine chloride, clarified in methyl salicylate and preserved as whole-mounts.

A brightfield microscope linked to software for image analysis (Image Pro Plus - Media Cybernetics) was

\footnotetext{
1. Disciplina de Parasitologia do Departamento de Patologia e Laboratórios da Faculdade de Ciências Médicas da Universidade do Estado do Rio de Janeiro, Rio de Janeiro, RJ. 2. Departamento de Imunologia do Centro de Pesquisa Aggeu Magalhães da Fundação Oswaldo Cruz, Recife, PE. 3. Laboratório de Helmintos Parasitos de Vertebrados do Departamento de Helmintologia do Instituto Oswaldo Cruz da Fundação Oswaldo Cruz, Rio de Janeiro, RJ. Supported by: UERJ, FAPERJ, CNPq

This work is part of a Master thesis at Mestrado de Morfologia - Instituto de Biologia - UERJ - RJ, Brazil

Address to: Dr. José Roberto Machado e Silva. Disciplina de Parasitologia/FCM/UERJ. R.Prof. Manoel de Abreu 48/5andar, Vila Isabel, 20551-170

Rio de Janeiro, RJ, Brazil.

Tel: 55 21587-6112.

e-mail:machado@uerj.br

Recebido para publicação em 10/10/2001.
} 
utilized. The following morphological parameters were studied for male worms: larger and smaller diameter, longer and shorter axis and perimeter for the testicular lobes. Female worms were studied according to the following parameters: area and perimeter of uterine eggs; area, larger and smaller diameter and perimeter of egg spine $^{19}$. Student's $t$ test was performed, values of $p<0.05$ were considered as significant for differences between the undernourished and control groups.

Morphometric data of male and female worms are given in Table 1. Specimens from undernourished mice showed lower values for all variables, when compared to those from well-fed mice. However, significant differences were only detected in males.

Morphological changes in the tegument and the reproductive system had been previously described in worms recovered from underfed animals ${ }^{6}{ }^{21}$. Reported data based upon morphometric studies now show that some components of the reproductive system may also be injured in undernourished hosts. These effects seem to relate to unavailability of nutrients in the blood of the vertebrate host ${ }^{21}$.

\begin{tabular}{lrr} 
Table 1 - Morphometric data of male and female adult worms of Schistosoma \\
mansoni recovered from undernourished and control mice. \\
\cline { 2 - 3 } & \multicolumn{2}{c}{ Mice } \\
\cline { 2 - 3 } & undernourished & control \\
Morphological parameters & $(\mathrm{X} \pm \mathrm{Sd})$ & $(\mathrm{X} \pm \mathrm{Sd})$ \\
\hline Males (testes lobes) & $(\mathrm{n}=35)$ & $316 \pm 50$ \\
larger diameter $(\mu \mathrm{m})^{*}$ & $278 \pm 55$ & $106 \pm 23$ \\
smaller diameter $(\mu \mathrm{m})^{*}$ & $89 \pm 16$ & $333 \pm 51$ \\
longer axis $(\mu \mathrm{m})^{*}$ & $296 \pm 62$ & $129 \pm 20$ \\
shorter axis $(\mu \mathrm{m})^{*}$ & $106 \pm 20$ & $814 \pm 118$ \\
perimeter $(\mu \mathrm{m})^{*}$ & $696 \pm 147$ & $(\mathrm{n}=20)$ \\
Female $($ eggs $)$ & $(\mathrm{n}=20)$ & $3756 \pm 636$ \\
area $\left(\mu \mathrm{m}^{2}\right)$ & $3470 \pm 556$ & $281 \pm 19$ \\
perimeter $(\mu \mathrm{m})$ & $274 \pm 22$ & $170 \pm 74$ \\
spine area $\left(\mu \mathrm{m}^{2}\right)$ & $162 \pm 66$ & $21 \pm 7$ \\
spine larger diameter $(\mu \mathrm{m})$ & $20 \pm 5$ & $10 \pm 3$ \\
spine smaller diameter $(\mu \mathrm{m})$ & $9 \pm 2$ & $58 \pm 18$ \\
spine perimeter $(\mu \mathrm{m})$ & $57 \pm 12$ &
\end{tabular}

It is known that, besides the host's nutritional status, several other factors can affect the host-parasite relationships, which may lead to several pathological manifestations. Any disturbances, therefore, in the microenvironment of the parasite can impair its biological behavior $^{8}$. Thus, supplementary food programs are recommended for those who inhabit endemic areas in order to improve their nutritional status ${ }^{8}$.

The nutritional status of the host can induce alterations in adult worms ${ }^{19}$. Worms recovered from underfed animals showed changes in the tegument and the reproductive system ${ }^{16}$. The data presented herein confirm such alterations and show that other characteristics (area, perimeter and spine size of uterine eggs and size of testicular lobes) are affected by the nutritional status of the host. This is probably due to changes in availability of nutrients within the host ${ }^{19}$.
As the surface architecture of the tegument allows the adult worm to ingest its nutrition ${ }^{1}$ and enhances migration of the worms against the bloodstream towards the site of oviposition, one can speculate that these alterations could impair the parasite behavior regarding several points. Since the effects of undernourishment are more severe in male worms and being well established that male worms supply nutrients for females ${ }^{10}$, these interactions may be disturbed. Furthermore, as males have a well-developed musculature, they are responsible for carrying females to the site of oviposition ${ }^{17} 18$. Obviously, if this does not occur, egg-laying and fecal egg-count can be altered. It must also be pointed out that nutrients can be ingested through the oral sucker or across their tegument ${ }^{22}$. Fatty acids for example are metabolized into complex lipids ${ }^{2}$ and absorbed glucose is used in the synthesis of glycogen ${ }^{22}$ stored by the schistosomes as their main energy source.

\section{REFERENCES}

1. Abath FG, Werkhauser RC. The tegument of Schistosoma mansoni: functional and immunological features. Parasite Immunology 18: 15-20, 1996.

2. Brouwers JF, Smeenk IM, van Golde LM, Tielens AG. The incorporation, modification and turnover of fatty acids in adult Schistosoma mansoni. Molecular Biochemical and Parasitology 88: 175-185, 1997.
3. Coutinho EM. Estado nutricional e esquistossomose. Revista da Sociedade Brasileira de Medicina Tropical 13: 91-96, 1980.

4. Coutinho EM, Abath FG, Barbosa CS, Domingues AL, Melo MC, Montenegro SM, Lucena MA, Romani SA, Souza WV, Coutinho AD. Factors involved in Schistosoma mansoni infection in rural areas of northeast Brazil. Memórias do Instituto Oswaldo Cruz 92: 707-715, 1997. 
5. Coutinho EM, Ferreira HS, Freitas LPCG, Silva MR, Cavalcanti CL, Samico MJA. Nutrition and acute schistosomiasis. Memórias do Instituto Oswaldo Cruz 87:297-301, 1992.

6. DeWitt WB. Experimental schistosomiasis mansoni in mice maintained on nutritionally deficient diets: II Survival and development of Schistosoma mansoni in mice maintained on a Torula yeast diet deficient in factor 3 , vitamin E and cystine. Journal of Parasitology 43:129-135, 1957.

7. Duvall RH, DeWitt WB. An improved perfusion technique for recovering adult schistosomes from laboratory animals. American Journal of Tropical Medicine and Hygiene 16:483-486, 1967.

8. Ferreira HS, Coutinho EM. Should nutrition be considered as a supplementary measure in schistosomiasis control? Annals of Tropical Medicine \& Parasitology 93: 437-447, 1999.

9. Kastner MRQ, Kohn A, Teixeira ED \& Pitanga LC. Estudo morfológico do Schistosoma mansoni Sambon, 1907 encontrado na espécie humana. Revista da Sociedade Brasileira de Medicina Tropical 9:247-261, 1975.

10. Kunz W. Schistosome male-female interaction: induction of germcell differentiation. Trends in Parasitology 17, 227-231, 2001.

11. Machado-Silva JR, Galvão C, Oliveira RMF, Presgrave OAF, Gomes DC. Schistosoma mansoni Sambon, 1907: comparative morphological studies of some Brazilian strains. Revista do Instituto de Medicina Tropical de São Paulo 37:441-443, 1995.

12. Machado-Silva JR, Galvão C, Presgrave OA, Rey L, Gomes DC. Host-induced morphological changes of Schistosoma mansoni Sambon, 1907 male worms. Memórias do Instituto Oswaldo Cruz 89: 411-416, 1994.

13. Machado-Silva JR, Lanfredi RM, Gomes DC. Morphological study of adult male worms of Schistosoma mansoni Sambon, 1907 by scanning electron microscopy. Memórias do Instituto Oswaldo Cruz 92: 647-653, 1997.

14. Machado-Silva JR, Pelajo-Machado M, Lenzi HL, Gomes DC. Morphological study of adult male worms of Schistosoma mansoni
Sambon, 1907 by confocal laser scanning microscopy. Memórias do Instituto Oswaldo Cruz 93: 303-307, 1998.

15. Magalhães LA, Carvalho JF. Estudo morfológico de Schistosoma mansoni pertencentes a linhagens de Belo Horizonte (MG) e de São José dos Campos (SP). Revista de Saúde Pública de São Paulo 7:289-294, 1973.

16. Magalhães LA, Guaraldo AM, Zanotti-Magalhães EM, Carvalho JF, Sgarbieri VC, Alcântara FG. Schistosomiasis mansoni in experimentally malnourished mice. Revista de Saúde Pública de São Paulo 20: 362-368, 1986.

17. Mair GR, Maule AG, Day TA, Halton DW. A confocal microscopical study of the musculature of adult Schistosoma mansoni. Parasitology 121: 163-170, 2000.

18. Morand S, Müller-Graf CDM. Muscles or testes? Comparative evidence for sexual competition among dioecious blood parasites (Schistosomatidae) of vertebrates. Parasitology 120: 45-56, 2000.

19. Neves RH, Machado-Silva JR, Pelajo-Machado M, Oliveira SA, Coutinho EM, Lenzi HL, Gomes DC. Morphological aspects of Schistosoma mansoni adult worms isolated from nourished and undernourished mice: a comparative analysis by confocal laser scanning microscopy. Memórias do Instituto Oswaldo Cruz 96: 1013-1016, 2001.

20. Neves RH, Pereira MJS, Gomes DC, Oliveira RMF, MachadoSilva JR. Morphometric differences of adult worms from sympathic samples of Schistosoma mansoni Sambon, 1907 isolated from rodents and humans. Memórias do Instituto Oswaldo Cruz 93: 309-312, 1998.

21. Oliveira SA, Barbosa Jr AA, Gomes DC, Machado-Silva JR, Montarroyos V, Barros AF, Coutinho EM. The morphology and morphometry of adult Schistosoma mansoni recovered from undernourished infected mice. Revista da Sociedade Brasileira de Medicina Tropical 34: 157-158, 2001.

22. Skelly PJ, Tielens AGM, Shoemaker CB. Glucose transport and metabolism in mammalian-stage schistosomes. Parasitology Today 14: 402-406, 1998. 